\title{
SUSTAINABILITY IN AGRICULTURE AND ALIENATION IN PEASANTRY: ARGUMENTS DERIVED FROM THE CASE OF TURKEY
}

\author{
Nevzat Evrim ÖNAL ${ }^{1}$, Burhan ÖZALP²
}

\begin{abstract}
Industrial agriculture, unlike traditional agriculture, relies solely on high yield and profit. All the problems attributed to it are directly or indirectly linked to this single-purpose nature. However, the industrialization of agriculture does not proceed only in large holdings belonging the rich farmers: The small holdings, under a multilayered pressure exerted by large scale capital dominating the input, output and credit markets, also resort to these production methods. This creates a vicious circle through which small-scale producers, due to increasing costs, price volatilities and indebtedness, gradually lose control of their economic activity. Peasants under this pressure have to use industrial, even prohibited inputs, knowing very well the harm they cause to the environment and consumers. Additionally, they are perfectly aware that the capital holders controlling the input-output and credit markets gain profit by appropriating their labor through price mechanisms. Under these contradictory conditions, agricultural production loses all the traditional meaning attributed to it for the peasant. The peasant is thus alienated from his produce in a way that is similar (but not exactly the same) to worker's alienation to his labor power. This study investigates the example provided by Çukurova Region in Turkey to present arguments on the link between sustainability (or the lack thereof) and peasant alienation.
\end{abstract}

Keywords: Sustainable agriculture, petty commodity production, alienation, Turkey

JEL Classification: N55, O13, Q13

\section{TÜRKIYE ÖRNEĞİNDE ORTAYA ÇIKAN TARIMDA SÜRDÜRÜLEBİLİRLİK VE KÖYLÜ KESIMINDEKI YABANCILAŞMA ARGÜMANLARI}

\begin{abstract}
Özet
Geleneksel tarımın aksine endüstriyel tarım yalnızca verim ve kâr üzerine kuruludur. Ona atfedilen tüm sorunların doğrudan ya da dolaylı kaynağında bu tek yönlülük bulunur. Ne var ki, tarımın endüstrileşmesi yalnızca zengin çiftçilere ait olan büyük ölçekli işletmelerde gerçekleşmez. Küçük ölçekli işletmeler de girdi, çıktı ve kredi piyasalarına egemen olan büyük ölçekli sermayenin çok katmanlı basıncı altında bu üretim metotlarını benimsemek zorunda kalırlar. Bu, küçük ölçekli üreticinin yükselen maliyetler, fiyat oynaklıklar ve borçluluk nedeniyle tedricen kendi iktisadi faaliyeti üzerindeki kontrolü yitirdiği bir kısır döngü yaratır. Bu basınç altındaki çiftçiler endüstriyel, hatta kullanılması yasak girdileri, çevreye ve toprağa zararlı olacağını pekala bilerek kullanmak zorunda kalırlar. Buna ek olarak, girdi, çıktı ve kredi piyasalarını kontrol eden sermayenin fiyat mekanizmaları kanalıyla emeklerine el koyduğunun da açıkça farkındadırlar. Bu çelişkili koşullarda, tarımsal üretim küçük ölçekli üretim yapan çiftçiler için ona atfedilen tüm geleneksel değerleri yitirir. Böylelikle çiftçi ürününe, işçinin emek gücüne yabancılaşmasına çok benzer (ama tam olarak aynı olmayan) bir biçimde yabancılaşır. Bu çalışmada, Türkiye'nin Çukurova bölgesinden çekilen bir örneklemden yararlanılarak sürdürülebilirlik (ya da sürdürülemezlik) ile çiftçi yabancılaşması arasındaki bağlantı üzerine argümanlar sunulacaktır.
\end{abstract}

Anahtar Kelimeler: Sürdürülebilir tarım, küçük meta üretimi, yabancılaşma, Türkiye

JEL Sinıflaması: N55, O13, Q13

1 Dr. Öğr. Üyesi, Beykoz Üniversitesi, Mühendislik ve Mimarlık Fakültesi, İşletme Mühendisliği Bölümü, nevzatevrimonal@,beykoz.edu.tr

2 Arş. Gör., Çukurova Üniversitesi, Ziraat Fakültesi, Tarım Ekonomisi Bölümü, burhanzalp@gmail.com 


\section{Introduction}

The last decade has seen a revival in the discussion, both popular and academic, about what should be (or naturally are) the characteristics of agricultural production that is best suited to human needs.

The health and environment concerns arising from the practices of industrial farming had a longer background. The practices of industrial agriculture and their impact on environment, economy and society have been questioned and a sustainable alternative for agricultural production sought since the beginning of 1990s (Reganold, Papendick and Parr, 1990). These criticisms were augmented and carried into the next decade as it became apparent that the adverse results of industrial agriculture are as harmful as industrial or urban pollution (Turhan, 2005). From these arguments, the term "sustainable agriculture," meaning an approach to agriculture seeking to balance its agronomical, environmental, social and economic dimensions using methods that do not create negative externalities and focus solely of productivity but on increasing the capacity of natural inputs, was formulated (Khan, 2011).

With the soaring of food prices during the first years of the global crisis (FAO, 2017) the main argument of the green revolution, which proposed that industrial farming will provide cheap and abundant food for everybody, also collapsed. This environment strengthened the populist theses which propose that small-scale, family farming should be favored over large-scale industrial farming because the former, being "peasant mode of production" is (a) more in harmony with the ecological system and do not contain hazards to human health like the latter, and (b) more resilient to the fluctuations in the economy since it is external to the capitalist mode of production.

This study aims to present arguments against these theses. These arguments will be derived from the case of maize farmers in the Çukurova region of Turkey which shows that the practices used in small-scale family production is neither more environment friendly nor healthier, precisely because it is not external to the capitalist mode of production.

The study will be presented in three sections. The first section will outline the theoretical framework of the study. The second section, which will be divided into two subsections, will present the background, rationale and findings of the empirical study. The third section will present the conclusions.

\section{Theoretical framework: Peasantry, commodification and alienation}

The definition of "peasantry" within the framework of class analysis has been a topic of serious debate (Ennew, Hirst and Tribe, 1977; Patnaik, 1979; Bernstein, 1979). As capitalist relations of production and circulation penetrate agricultural production, the people engaged in it become segregated into the capitalist class structure so that it becomes impossible to speak of a homogenous peasantry consisting of simple commodity producers anymore. However, in many cases, the transformation of agriculture does not follow the same pattern of industry where large scale capitalist production drives almost all of the small-scale artisanal producers to bankruptcy. Between the capitalist farmers who employ wage labor to accumulate capital and the rural workers (who may or may not be completely landless themselves) who sell their labor force to live, there remains a large social group which Bernstein (1979: 431) defines as the "middle peasantry". These people, living as household units, mainly work their own land using mainly family labor and their primary and indispensible source of income comes from selling their produce. These can be seen as the petty bourgeoisie of the countryside; and henceforth the term "peasant" will be referring to these. 
However, no social construct can be defined as a thing in itself since it comes into existence and reproduces itself through social relations. Therefore, it is misleading (and ahistorical) to imagine a multitude of non-capitalist family farms, with or without relation to each other, coexisting in symbiotic relationship to capitalist mode of production yet remaining external to it; because it is the relation that defines the construct and not the other way around. The relations of circulation, through which the peasantry reproduces itself, also integrate it into the capitalist system and transform it.

The key concept here is commodification. Under capitalist mode of production, any good that will circulate in the market has to be a commodity (Marx, [1867] 2017a); it has to have an exchange-value, defined in monetary terms as its price, which constantly changes in accordance to its scarcity or abundance. The peasant sells its produce in the market to buy a variety of goods to satisfy its needs. However, it has no control over the price of its produce because to control the price of a commodity, one needs to control the scarcity or abundance of it. This is achieved through monopolization, and it is by definition the thing that is impossible for the small-scale producer. Therefore, market integration means entering into relations with larger capital and this inevitably results in dependency.

One aspect of this is becoming dependent on the market to satisfy needs; ending subsistence production and using all the family labor to produce commodities. However, this is usually brought about by becoming dependent on capital to sell produce, and ultimately, to engage in production altogether. Generally, the peasantry is coerced through economic and extra-economic means into market relations rather than enter them willingly (Marx, [1852] 2017b; Bernstein, 1979: 426). In time, the peasantry is "squeezed" (Bernstein, 1979: 427) through unequal terms of exchange since it cannot control the prices while the capital which sells seeds, fertilizers etc. to it, and the capital which buys its produce, to an extent, can.

However, this does not usually result in total ruin of small-scale production. On the contrary, the market relations which reduce the income of the peasant do not squeeze it out of existence but make its impoverished existence sustainable. Since the peasant is not selling its labor in return of wages but its produce in return of profit; it can work for less return on its labor than an average worker to sustain its precarious existence. This is also more profitable for the large-scale capital since the alternative is driving out the peasant and engaging in the production of agricultural raw materials using wage labor; in which case, decreasing the wages of workers will be much harder than cutting the farm-gate prices of small-scale producers.

This is the result of an important difference between the peasant and the worker. The dispossessed worker has only his labor power to sell; therefore he is alienated to it and is more inclined to ask for higher wages for it (Marx, [1844] 2017c). The peasant, on the other hand, since he still owns the means of production, is not alienated to his own labor power as the worker is. The price he will attempt to negotiate on is the price of his produce, not labor. However, this also means that unlike what some advocates of the "peasant mode of production" claim, he is completely alienated to the use-value of his produce and is concerned of its quality, healthiness, environmental impact et cetera insofar as it will result in a higher or lower exchange-value and influence his monetary income.

\section{Empirical study}

This section of the paper consists of two subsections: The first one will outline the rationale of the empirical study, presenting the reasons why maize production in Çukurova region was selected as the object of inquiry. After that, the details of the field study and its findings will be presented in the second subsection.

\subsection{Background and Rationale}

The employment structure of Turkish agriculture has undergone some changes in the last 15 years but can still be defined as primarily family-driven. However, the data of Adana and Mersin provinces (more detailed regional data is unavailable) show that agriculture in this region uses a considerably higher number of paid workers than the rest of the country. The data on this is presented in Table 1 . 
Table 1: Employment Structure in Agriculture (thousand persons)

\begin{tabular}{|c|c|c|c|c|c|c|}
\hline & Year & Paid worker & Employer & Self-employed & $\begin{array}{c}\text { Unpaid family } \\
\text { worker }\end{array}$ & Total \\
\hline \multirow{3}{*}{ Turkey } & 2004 & 487 & 105 & 3031 & 3934 & 7557 \\
\hline & 2015 & 599 & 48 & 2209 & 2627 & 5483 \\
\hline & Year & Paid worker & \multicolumn{2}{|c|}{$\begin{array}{c}\text { Employer } \\
\text { and/or } \\
\text { Self-employed* }\end{array}$} & $\begin{array}{c}\text { Unpaid family } \\
\text { worker }\end{array}$ & Total \\
\hline \multirow{2}{*}{$\begin{array}{l}\text { Adana and } \\
\text { Mersin }\end{array}$} & 2004 & 54 & \multicolumn{2}{|c|}{112} & 58 & 223 \\
\hline & 2014 & 80 & \multicolumn{2}{|c|}{96} & 87 & 263 \\
\hline
\end{tabular}

Source: Turkstat (2017)

* Turkstat statistics do not cover the two categories separately in regional data

Çukurova (literally meaning "bowl plain") region is chosen as the locale of this study since it presents one of the most developed examples of commodification in Turkish agriculture. It was one of the first agricultural regions to be connected to world markets during the last century of Ottoman rule. This was facilitated mostly by British colonial empire which, using railroad privileges taken from Ottoman Sultan, laid railroads from ports into their fertile hinterland, unequally commercializing regions. During these years, Mersin-Adana railroad tied Çukurova region to Mersin port (Kurmuş, 2007:100-107) and with this connection, the agricultural produce of the region was swiftly transformed by world demand for industrial raw material; particularly cotton. This transformation was particularly pronounced because the region was transformed into an alternate source for cotton by the British merchants during the years of American Civil War when the Confederate side tried to use the cotton produced at the plantations in southern states as a leverage to pull the British Empire to their side (Quataert, 1980:42).

After the establishment of Turkish Republic, one of the first items in the planned industrialization of the country was the production of cotton cloth. This was done through a state company named Sümerbank (Önal, 2010). Until its privatization in the beginning of the 21st century, Sümerbank provided price subsidies to cotton farmers by buying almost all the cotton produced in Turkey and supplied cheap cloth for Turkish textile industry. After its privatization and eventual dismantlement of its cloth factories, almost all cotton producers in Çukurova region turned to maize production, which is much easier to sell in the private market.

Apart from these, maize is also chosen as the object of study because industrial inputs are widely used in its production and it is an important field crop which is used both as animal feed and for human consumption. This is also reflected in the evolution of maize production in Turkey. Area-wise, maize seems an unimportant item in the production of cereals in Turkey, covering only 4\% of total cereal area sown in 2001 and $6 \%$ in 2015. However, the yield per hectare more than doubles in this period (from 4 tons to 9.3) and the share of maize in total cereal production rises from $7.4 \%$ to $16.6 \%$. This unusual rise in productivity suggests a rise in the use of industrial inputs, particularly hybrid seeds.

Çukurova region (Adana, Mersin, Hatay and Osmaniye provinces) produces $28 \%$ of all maize produced in Turkey from $24 \%$ of all area sown with maize; therefore, the yield per hectare is considerably higher in this region than Turkey average. Adana province alone produces $16 \%$ of all maize in Turkey and $57 \%$ in the region while Ceyhan and Yüreğir, the two towns chosen for this study, produce 59\% percent of all maize in Adana. 


\subsection{Findings}

Farmer Registration System data taken from Adana Food, Agriculture and Livestock Provincial Directorship shows that there are 3957 maize farmers in Ceyhan and Yüreğir towns ${ }^{3}$. Of these, a sample of 94 individuals was randomly chosen for face-to-face interview using a set questionnaire made up mostly of yes-no and likert scale (1strongly disagree; 5 -strongly agree) questions. Sample size was determined using adjusted minimum sample size formula (Saunders, Lewis and Thornhill, 2009) for 95\% confidence interval, 10\% error margin and 50\% answer rate $^{4}$ :

Sample size formula: $n=\% p \times \% q \times\left(\frac{z}{\% e}\right)^{2}$

Adjusted minimum sample size formula: $n^{\prime}=\frac{n}{1+\frac{n}{N}}$

- $\quad$ N: Population size

- $\mathrm{n}$ : Sample size

- $\quad$ n': Adjusted minimum sample size

- $\quad \mathrm{p}$ and q: Response distribution

- $\quad \mathrm{z}$ : Confidence interval

- e: Error margin

This method allowed the study to narrow the types of answers given and group similar ones into quantifiable categories, presenting averages and percentages when necessary, while the personal contact provided by the interview allowed important individual remarks to be noted. Both the quantified results and the individual remarks were used as guidelines in constructing a qualitative analysis of the case studied. Therefore, the data presented below should be taken as the basis for the analysis which will be presented in the conclusion chapter, not as the analysis itself.

The sample average age, monthly income and field area used in maize production are 50 years, 1655 Turkish Liras ${ }^{5}$ and 16.5 hectares respectively.

The first important finding of the study is that all the subjects in the sample said that they used commercial seeds in producing maize. When asked which brand of seed they used, the answers, presented in Table 2, show that the seed market in the region is seriously monopolized between two brands ${ }^{6}$.

\footnotetext{
${ }^{3}$ Farmer Registration System data is not open-access and is taken through individual query.

${ }^{4}$ The database for answers was prepared and analyzed using SPSS program.

${ }^{5}$ Approximately 560\$ during the period in which the interviews were done (May 2016)

${ }^{6}$ This is an enhanced reflection of the worldwide situation in the seed market where the first ten producers control $75.3 \%$ of the seed market (ETC Group, 2013).
} 
Table 2: Share of commercial seed brands in the market

\begin{tabular}{|l|c|c|c|c|c|c|c|c|c|c|}
\hline $\begin{array}{l}\text { Seed Brand } \\
\text { (B1, B2 } \ldots)\end{array}$ & B1 & B2 & $\begin{array}{c}\text { B1 and } \\
\text { B2 }\end{array}$ & B3 & $\begin{array}{c}\text { B1 and } \\
\text { B3 }\end{array}$ & $\begin{array}{c}\text { B2 and } \\
\text { B3 }\end{array}$ & $\begin{array}{c}\text { B1, B2 } \\
\text { and B3 }\end{array}$ & B4 & B5 & Total \\
\hline Share (\%) & 47 & 19 & 24 & 1 & 4 & 1 & 1 & 2 & 1 & 100 \\
\hline
\end{tabular}

Yield and marketability are the main concerns of the subjects when choosing which seed to plant, indicating a strong market orientation. In the interviews, the subjects also mention that the marketability of maize produced from different seed brands vary according to the preferences of the merchants and these preferences are usually made known to the producers beforehand. Interestingly, the environment factor scores higher in producers concerns than the nutritious properties of the produce or the price of seed. The strengths of the factors that affect the peasants' seed choices are shown in Table 3.

Table 3: Factors that define the producers' choice of seed

\begin{tabular}{|c|c|c|c|c|c|c|}
\hline ("I choose seed according to...) & 1 & 2 & 3 & 4 & 5 & $4+5$ \\
\hline Yield & 4 & 4 & 0 & 7 & 84 & 92 \\
\hline Marketability of the maize produced & 2 & 5 & 2 & 38 & 53 & 91 \\
\hline Contribution to ecological balance & 19 & 14 & 16 & 48 & 3 & 52 \\
\hline Nutritiousness property of the maize produced & 24 & 17 & 13 & 40 & 6 & 46 \\
\hline Price & 30 & 33 & 2 & 14 & 22 & 36 \\
\hline
\end{tabular}

Another important point is the use of fertilizers. All the subjects indicate that they use chemical fertilizers regularly while the usage rate of organic fertilizers is quite low. $62 \%$ of the subjects say that they never use organic fertilizers while $28 \%$ say they infrequently use such fertilizers. Among the subjects, only $10 \%$ say that they regularly use organic fertilizer.

Soil analysis for fertilization is made by $61 \%$ of the subjects, but only $14 \%$ determine the fertilizer type and quantity according to soil analysis. $63 \%$ of the subjects claim that they determine the fertilizer variety and its quantity according to common practice.

An interesting finding is about the opinion of the producers on whether or not the chemical fertilizers are harmful. The majority of the subjects express negative opinions about the effect of chemical fertilizers on health, environments and the quality of the soil; however, none of them refrains from using them. These findings are presented in Table 4. 
Table 4: Opinions of the producers about the harmful effects of chemical fertilizers

\begin{tabular}{|l|c|c|c|c|c|c|}
\hline & 1 & 2 & 3 & 4 & 5 & $4+5$ \\
\hline The fertilizers I use harm the soil and make it infertile over time & 4 & 17 & 0 & 39 & 40 & 79 \\
\hline The fertilizers I use harm the beneficial organisms in the soil & 3 & 19 & 8 & 37 & 33 & 69 \\
\hline The fertilizers I use foul underground waters and streams & 2 & 16 & 8 & 37 & 37 & 74 \\
\hline $\begin{array}{l}\text { Product which I produce using chemical fertilizers has harmful effects for } \\
\text { human health }\end{array}$ & 3 & 21 & 7 & 31 & 38 & 68 \\
\hline Cronbach's Alfa: 0.876 &
\end{tabular}

Use of pesticides is a similar issue. All the subjects use pesticides. Of the sample, $87 \%$ use pesticides two times while $13 \%$ use three times during one crop cycle. When asked on which condition they do so, $51 \%$ respond that they use pesticide when they notice pests or plant diseases in the crops while $46 \%$ say that they use pesticides for precaution even if no pest or plant disease is visibly present. Only $3 \%$ of the subjects say that they use pesticides in accordance to the advices of agriculture experts.

The subjects' opinions on the harmful effects of the pesticides are similar to their opinions about chemical fertilizers, only stronger. These are presented in Table 5.

Table 5: Opinions of the producers about the harmful effects of pesticides

\begin{tabular}{|l|c|c|c|c|c|c|}
\hline & 1 & 2 & 3 & 4 & 5 & $4+5$ \\
\hline The pesticides I use harm the soil and make it infertile over time & 3 & 22 & 5 & 34 & 36 & 70 \\
\hline The pesticides I use harm the beneficial organisms in the soil & 0 & 12 & 1 & 43 & 44 & 87 \\
\hline The pesticides I use foul underground waters and streams & 0 & 17 & 6 & 40 & 37 & 77 \\
\hline Product which I produce using pesticides has harmful effects for human health & 0 & 11 & 7 & 39 & 43 & 82 \\
\hline Cronbach's Alfa: 0.809
\end{tabular}

The term "sustainable agriculture" is not a mystery among maize peasants. $68 \%$ of the subjects say that they know the definition of the term. However, only $12 \%$ of them have participated in some training on the subject. Therefore, when asked why they keep using conventional methods of production, 74\% say that they don't know any other method, while $92 \%$ say that conventional production methods are easier to implement than sustainable agriculture practices. The breakdown of the answers on this is presented in Table 6.

Table 6: Conventional vs. sustainable agriculture

\begin{tabular}{|l|c|c|c|c|c|c|}
\hline $\begin{array}{l}\text { (I produce maize by using hybrid seed, chemical fertilizer and chemical pesticide } \\
\text { because...) }\end{array}$ & 1 & 2 & 3 & 4 & 5 & $4+5$ \\
\hline I don't know any other production method. & 5 & 9 & 12 & 35 & 38 & 74 \\
\hline That method is easier than sustainable agriculture method. & 0 & 5 & 3 & 58 & 34 & 92 \\
\hline Cronbach's Alfa: 0.730 & \multicolumn{4}{|l}{} \\
\hline
\end{tabular}


As would be expected, there is a very high ratio of loan usage (77\%) among the subjects. However, more important than this is the way loans are used. Maize producers mainly use loan as working capital (for buying inputs and, more importantly, paying back older loans) and those who use loans for investment are in the minority, meaning that there is a smaller chance for the majority of producers to free themselves from the cycle of indebtedness. Reasons for loan usage among maize producers are presented in Table 7.

Table 7: Reasons of loan usage among maize producers (\%)

\begin{tabular}{|c|c|c|c|}
\hline Working Capital & Investment & Working Capital and Investment & Other \\
\hline 84 & 3 & 11 & 3 \\
\hline
\end{tabular}

Another important issue is the marketing of produce. Research shows that none of the producers have direct market connections with the buyers. Besides, the presence of the state apparatus on regulating cereal production (Turkish Grain Board - TMO) is also next to nonexistent. $93 \%$ of the subjects sell all their produce to merchants while 5\% sell their some of their produce to merchants and some of it to TMO. Only $2 \%$ of the subjects sell all their produce to TMO.

Therefore, the insecurity caused by market fluctuations is very prominent. When asked about price expectations on inputs, almost all the subjects say that they expect the input prices to increase. This expectation is weaker in loan interests since interest rates have been somewhat stable in Turkey over the last decade. On the other hand, when asked about their expectations on the price of their produce and support payments, the subjects express mixed opinions. These are presented in Table 8 .

The expectation of the producers that the price mechanisms will work against their interests is created more through years of experience (recall that sample average age is 50) than any economic evaluation and this is not the most important point. It should be noted here that the change in farm gate price of maize fell significantly behind the change in the price of all agricultural inputs as well as main household equipment between 2002 and 2015 (Ministry of Agriculture, 2015:16). What is more important is the market imperative that forces them, even with this expectation, to keep to the methods in which they use higher inputs for higher yields. This point will be expanded in the conclusion.

Table 8: Expectations on input and output prices, interest rate and government support (\%)

\begin{tabular}{|l|c|c|c|c|}
\hline & Increase & Decrease & No Change & No idea \\
\hline Maize price & 44 & 13 & 43 & 0 \\
\hline Fertilizer price & 84 & 4 & 12 & 0 \\
\hline Pesticide price & 94 & 1 & 5 & 0 \\
\hline Diesel fuel price & 93 & 4 & 3 & 0 \\
\hline Interest rate on agricultural loan & 54 & 6 & 33 & 6 \\
\hline Agricultural supports & 28 & 25 & 45 & 1 \\
\hline
\end{tabular}

It was noted in the beginning of this chapter that Çukurova region has a higher ration of paid employment in agriculture than the rest of Turkey. This is also reflected in the answers to questions concerning the organization of labor on the farm. $59 \%$ of the subjects employ paid workers at least in some seasons. At the same time, $33 \%$ of the farms have at least one family member working in a temporary or permanent job $(55 \%$ in and $45 \%$ out of agriculture) outside the farm. Paid labor is important in the managing of the farm and $54 \%$ of the subjects say that they will not be able to manage the farm without employing workers. 
Finally, the attitude of the peasants against their own livelihood is bleak (Table 9). When asked why they keep on their occupation as an agricultural producer, a large majority reply that they cannot do anything else. Very few of them find farming profitable but some think that their lot will improve in the future. Another reason given by the subjects for living as an agricultural producer is providing an employment guarantee for their children. Interestingly, when asked about the future of their family, $70 \%$ of the subjects say they would prefer their children not to make their livelihood from agriculture.

Table 9: Reasons for keeping to agricultural production as occupation

\begin{tabular}{|l|c|}
\hline & $\%$ \\
\hline I cannot do any job except for farming (1) & 68 \\
\hline Farming is a profitable job (2) & 5 \\
\hline I think that that farming will be better in the future (3) & 21 \\
\hline To create employment area for my children (4) & 4 \\
\hline 3 and 4 & 1 \\
\hline
\end{tabular}

\section{Conclusions}

This study investigated the case of maize farmers in Çukurova region of Turkey with the aim of presenting an argument against the populist view that assumes small-scale production in agriculture is ipso facto healthier, more environment friendly and altogether sustainable that industrial agriculture. While the adverse effects of industrial agriculture to human health and environment are obvious ${ }^{7}$, there is no basis to assume that small-scale producers who are trying to make their living by selling their produce engage in healthier practices. On the contrary, the competition in the market forces each producer to increase production by using industrial inputs and this, in turn, pushes down prices. Coupled with the fact that the industrial capital providing inputs, banking capital providing loans and merchant capital buying outputs are much larger and concentrated, this creates an impasse for the smallscale producers in which they constantly have to push for higher productivity on their limited land to maintain a steady income. This is a vicious cycle which does not altogether ruin the peasant family but squeeze its income to the level of bare subsistence.

The findings of the study reflect this in various ways. The average income of the maize producer family is equal to minimum wage ${ }^{8}$ even if in almost all family farms more than one family members work. All the producers expect the price of their inputs to rise while they do not expect a similar rise in the price of maize or the agricultural support payments. They are dependent to a highly monopolized seed market; all of them use chemical fertilizers and pesticides and almost all of them sell their produce to merchants who, in some cases, are also the regional wholesalers of their industrial inputs. Three maize producers out of every four are in debt and most of them use their loans not for investment but as working capital (or to roll their debt). Under these conditions, the maize farmers, most of who are well past their adulthood and cannot make a living in any other way, present a bleak outlook: Very few of them want their children to keep farming yet they are compelled by the squeezing cycle they are in to keep producing.

This brings about the alienation problem noted in the first section of this study. The maize farmers, although they do not directly sell their labor power to capital, have no control on their production whatsoever. Therefore, since the quality of their produce would make no difference in the wholesale market, they disregard any concern of health or environment.

\footnotetext{
${ }^{7}$ It is beyond the scope of this study to question this argument.

${ }^{8}$ The minimum gross wage at the time of this study was 1647 Turkish Liras while the sample average income was 1655 Turkish Liras.
} 
A great majority of the subjects openly state that they know the hazards of using chemical inputs to human health, environment and sustainability of agriculture, yet they have no choice but to keep to these harmful practices.

One thing that should be noted with this is the obvious causality between commodification and alienation. Founding of sales cooperatives is frequently presented as a solution but this is doubtful because of two reasons. (1) Sales cooperatives do not operate outside the rules of market capitalism; they are basically collective firms. Therefore, although they may help to alleviate the material conditions of peasantry, they will not solve the problems concerning human health and environment since the root of these problems lie in the practices that are directly the result of producing for profit. (2) To be effective, these cooperatives will need to have a large amount of capital so that they can compete in the market. It is not clear where this capital will come from if not the state. However, the contemporary hegemonic ideas concerning the political economy of the state do not look favorably on supporting transfer expenditures towards agriculture, particularly those that interfere with the working of market economy (WTO, 2017). For example, the Turkish state had foregone budget support to agricultural sales cooperatives in the structural adjustment program implemented with IMF after the economic crisis of 2001 (Önal, 2010:167)

However, under present conditions, this is a problem that cannot be solved without an intervention from outside the market, which means it will have to somehow involve state authority. A suggestion on the scope and scale of this intervention is beyond the scope of this study, but from the findings and their interpretation carried out, it is obvious that this intervention would have to suppress profit-seeking behavior in agricultural production if it will solve the many intertwined problems concerning it.

\section{References}

Action Group on Erosion, Technology and Concentration (ETC Group). (2013). Putting the cartel before the horse ...and farm, seeds, soil, peasants, etc. (Communiqué no. 111, September 2013). Retrieved from http://www.etcgroup.org.

Bernstein, H. (1979). African peasantries: A theoretical framework. The Journal of Peasant Studies 6(4), 421443.

Ennew, J, Hirst P. and Tribe, K. (1977).'Peasantry’ as an economic category. The Journal of Peasant Studies. 4(4), 295-322.

Food and Agriculture Organization of the United Nations (FAO). (2017). Food price index. Retrieved from http://www.fao.org.

Khan, W. (2011). Feeding the developing world with sustainable agricultural methods: Possibilities, constraints, and proposals. Presented at 2011 Conference of the Association for Heterodox Economics, July 6-9, Nottingham Trent University, United Kingdom. Retrieved from: http://www4.ntu.ac.uk.

Kurmuş, O. (2007). Emperyalizmin Türkiye'ye girişi. $4^{\text {th }}$ ed. İstanbul: Yordam.

Marx, K. [1867] (2017a). Capital: Volume I. Retrieved from https://www.marxists.org.

Marx, K. [1852] (2017b). The Eighteenth Brumaire of Louis Bonaparte. Retrieved from https://www.marxists.org.

Marx, K. [1844] (2017c). Estranged labour. Retrieved from https://www.marxists.org.

Önal, N.E. (2010). Anadolu tarımının 150 yıllık öyküsü. İstanbul: Yazılama.

Patnaik, U. (1979). Neo-populism and Marxism: The Chayanovian view of the agrarian question and its fundamental fallacy. The Journal of Peasant Studies. 6(4), 375-420.

Quataert, D. (1980). The commercialization of agriculture in Ottoman Turkey, 1800-1914. International Journal of Turkish Studies. 1(2), 38-55. 
Reganold, J.P., Papendick, R.I. and Parr, J.F. (1990). Sustainable agriculture. Scientific American 262(6), $112-$ 120. Retrieved from https://www.researchgate.net.

Republic of Turkey Ministry of Food, Agriculture and Livestock. (2015). Tarımsal veriler. Retrieved from http://www.tarim.gov.tr.

Saunders, M.N.K., Thornhill A. and Lewis, P. (2009). Research methods for business students. Financial Times Prentice Hall.

Turhan, Ş. (2005). Tarımda sürdürülebilirlik ve organik tarım. Tarım Ekonomisi Dergisi .11(1), 13-24. Retrieved from http://journal.tarekoder.org.

Turkish Statistical Institute (Turkstat). (2017). Labor force statistics. Retrieved from http://www.turkstat.gov.tr.

World Trade Organization (WTO). (2017). Agriculture negotiations background fact sheet - domestic support in agriculture. Retrieved from https://www.wto.org. 